\title{
ペットボトルラベル再生ペレットの排水性 アスファルト混合物への混入効果
}

\author{
鎌田 修 ${ }^{1} \cdot$ 山田 優 ${ }^{2}$ \\ ${ }^{1}$ 学生会員 工修 大阪市立大学大学院工学研究科 (7588-8585 大阪市住吉区杉本3-3-138) \\ ${ }^{2}$ 正会員 工博 大阪市立大学大学院工学研究科教授 (§58-8585 大阪市住吉区杉本3-3-138)
}

\begin{abstract}
ペットボトルのリサイクルは進んでいるが, ラベル部分のポリエチレンは種々の色を呈しているために， プラスチック製品としての用途は限られている.また，これまでの研究て密粒度アスファルト混合物にポ リエチレンを混入すると耐流動性，耐曲げひひ割れ特性が向上することが分かっている．乥こで本研究で は，使用されることが多くなっている排水性アスファルト混合物に混入し，光の効果を調へた。 . 弚の結果， 水浸ホイールトラッキンク試験による破壊時間が大きくなり，また耐油残留安定度試験から残留安定度が 大きくなり，排水性混合物に求められる滞留水によるはく離破壞，車の油漏出による破壊に対する抵抗性 が向上することが分かった .
\end{abstract}

Key Words : the pellet reclaimed from PET bottle label, porous asphalt mixture, the time of destruction, anti-oil stability

\section{1. はじめに}

各種飲料用ペットボトルは，安価で軽量，かつ耐 衝撃性が優れ，我が国では近年使用量が急激に伸び ている. 2002 年度には生産量が 40 万 $\mathrm{t}$ に達しようと している . 世界的にも包装容器として話題を呼んで おり，世界全体の生産伸び率は我が国の伸び率より も大きく，今後も炎の傾向は続くと予想される .

しかし , ペットボトルのリサイクル率は $40 \%$ 以下 で, スチール缶 , アルミ缶の $80 \%$ 程度に比べて , ま だまだ低く，光れを高めるべく技術開発が要求され ている。

ペットボトルは通常, ポリエチレンテレフタレー 卜の本体にポリエチレンのラベルが巻かれている . 本体のほうはほとんど無色透明で,分離収集すれば， 再生ペレットにして樣々な用途に利用できる．ラべ ルのほうは種々の色を呈していてプラスチック製品 としての用途は限られ，リサイクルされにくい.

廃プラスチックの舗装材料としての利用について は,これまでの研究 ${ }^{1), 2)}$ から可能性が見いだされて いる．すなわち，密粒度アスファルト混合物にポリ エチレン , ポリプロピレンなど熱可塑性プラスチッ クの粒を混入した場合にはホイールトラッキング試 験より求められる動的安定度 (以下, DS) が上がり，
ポリエチレンはさらに耐曲げひび割れ特性も向上さ せることができる .

一方，道路舗装においては，表層に排水性アスフ アルト混合物を用いることが多くなっている .この 混合物はバインダーに高粘度アスファルトを使用し ていて, 従来の混合物に比べて塑性変形抵抗性など の点ですぐれている．しかし，重交通量の表層に用 いられることが多く，耐久性が重視される．特に， 排水性という機能から，混合物内に水が滞留するこ とがあり，はく離による破壊が心配される3゙．また， 車からの油の漏出が破壊につながりやすいことも指 摘されている ${ }^{4}$.

乥こで本研究では, ペットボトルのポリエチレン ラベルの再生ペレットを排水性アスファルト混合物 に混入し，特にはく離による破壊，油による破壊に 対する抵抗性を向上させることができないかなど， 混入効果を検討した。

\section{2.使用材料および混合物作製方法}

\section{（1）使用プラスチック種類}

本研究で使用したプラスチックを表- 1 に示す． ペットボトルラベル再生ペレット (以下 , PE-3) の 
ほか, 比較のために, ポリプロピ レンとポリエチレンの市販ペレッ 卜 (以下，PP および PE-1)，およ び過去に密粒度アスファルト混合 物に混入して現場施工の実績のあ るポリエチレンの廃棄物の破砕物 (以下，PE-2) を加え, 計 4 種類 とした .ペレットの PE-1 と PP の 粒径は 7 号砕石の粒径の 5 2.5 $(\mathrm{mm})$ でほぼ均一であった，廃 棄物の PE-2 は粒径が均一ではな かったが，ほぼ 6 号砕石の粒径の 13〜 5(mm)であった . PE-3 は粒度 分布が広範囲に分散していた。

（2）混合物の種類, およびその 材料と 配合

最大粒径が $13 \mathrm{~mm}$ と $5 \mathrm{~mm}$ の排 水性アスファルト混合物および比 較のために最大粒径 $13 \mathrm{~mm}$ の密粒 度アスファルト混合物を作製した。 弚れらの材料と配合を表- 2 に示 す。

\section{（ 3）混合物の作製方法}

プラスチックを混入する際は骨 材と体積比で置換して混入した . 置換する骨材の粒径は PP と PE-1 は 4.75〜2.36 $(\mathrm{mm})$ とし, 混入量を $4 \%$ または $8 \%$ とした . PE-2 は粒 径 9.5〜 4.75(mm)の骨材と $4 \%$ ま たは $8 \%$ 置換した . PE-3 は粒径に ばらつきが出たために，2.36〜 $0.075(\mathrm{~mm})$ の骨材と置換する範囲 を変えながら 4〜 10\%混入した 。

混合温度は排水性混合物で $170^{\circ} \mathrm{C}$ ，密粒度混合物で $150^{\circ} \mathrm{C}$ ， 混合時間はいずれも 150 秒とした . プラスチックは常温で添加し，150 秒間混合物と加 熱混合した。

ローラー転圧温度は排水性混合物で $150^{\circ} \mathrm{C}$ ，密粒 度混合物で $140^{\circ} \mathrm{C}$ とた。

\section{3.試験方法}

本研究では, プラスチック混入により排水性混合
表- 1 使用プラスチックの性状

\begin{tabular}{|c|c|c|c|c|c|}
\hline \multirow{2}{*}{\multicolumn{2}{|c|}{$\begin{array}{c}\text { 種類 } \\
\text { 呼び名称 }\end{array}$}} & ポリプロピレン & \multicolumn{2}{|c|}{ ポリエチレン } & \multirow{2}{*}{$\frac{\text { ポリエチレン }}{\mathrm{PE}-3}$} \\
\hline & & PP & $P E-1$ & $P E-2$ & \\
\hline & 品質 & 市販ペレット & 市販ペレット & 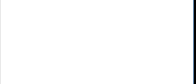 & 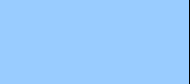 \\
\hline \multirow{10}{*}{$\begin{array}{l}\text { 通 } \\
\text { 過 } \\
\text { 質 } \\
\text { 量 } \\
\text { 百 } \\
\text { 分 } \\
\text { 率 } \\
(\%)\end{array}$} & $19.0 \mathrm{~mm}$ & - & - & 100.0 & - \\
\hline & 13.2 & - & - & 98.7 & - \\
\hline & 9.50 & - & - & 14.6 & 100.0 \\
\hline & 4.75 & 100.0 & 100.0 & 0.8 & 91.3 \\
\hline & 2.36 & 0.0 & 0.0 & 0.1 & 43.9 \\
\hline & 1.18 & - & - & - & 10.8 \\
\hline & 0.6 & - & - & - & 1.4 \\
\hline & 0.3 & - & -1 & - & 0.1 \\
\hline & 形状 & 球状 & 球状 & 砕石状 & 粒状 \\
\hline & 比重 & 0.921 & 0.900 & $0.900 *$ & $0.900 *$ \\
\hline
\end{tabular}

表- 2 使用混合物配合

\begin{tabular}{|c|r|r|r|r|}
\hline \multirow{2}{*}{\begin{tabular}{c} 
混合物の種類 \\
\cline { 2 - 5 }
\end{tabular}} & \multicolumn{2}{|c|}{ 排水性混合物 } & 密粒度混合物 & \multirow{2}{*}{ 備考 } \\
\hline
\end{tabular}

物にどのような影響を与えるか調べるために以下の 試験を行った .

・ホイールトラッキング試験（耐流動性の評価）

・水浸ホイールトラッキング試験

(耐水性，はく離特性の評価)

- 耐油残留安定度試験 (耐油性の評価)

- 現場透水試験（透水性への影響評価）

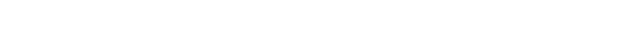




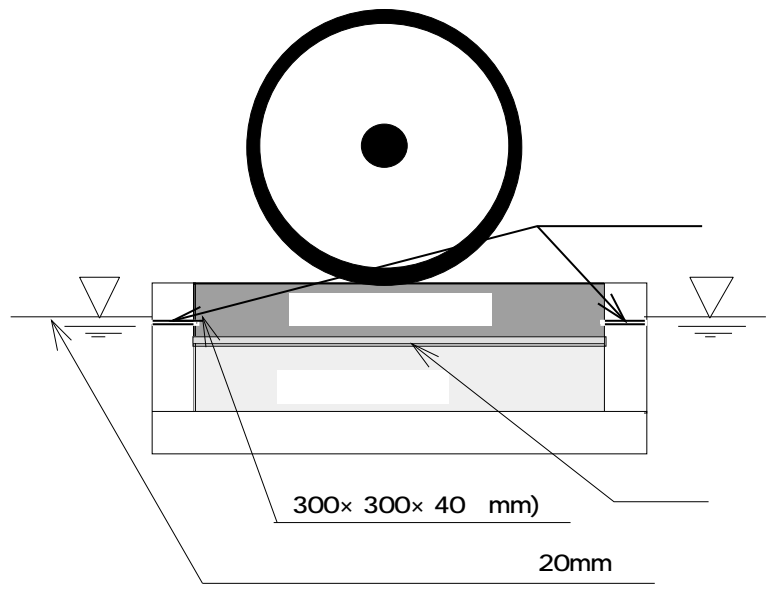

図- 1 水浸ホイールトラッキング試験装置概略図

表- 3 水浸ホイールトラッキング試験条件

\begin{tabular}{|c|c|}
\hline 項目 & 設定値 \\
\hline トラッキング速度 & 42 往復 $/$ 分 \\
\hline トラッキング幅 & $300 \mathrm{~mm}$ \\
\hline トラバース速度 & $100 \mathrm{~mm} /$ 分 \\
\hline トラバース幅 & $250 \mathrm{~mm}$ \\
\hline 室温・水温 & $60^{\circ} \mathrm{C}$ \\
\hline 荷重 & $686 \mathrm{~N}$ \\
\hline
\end{tabular}

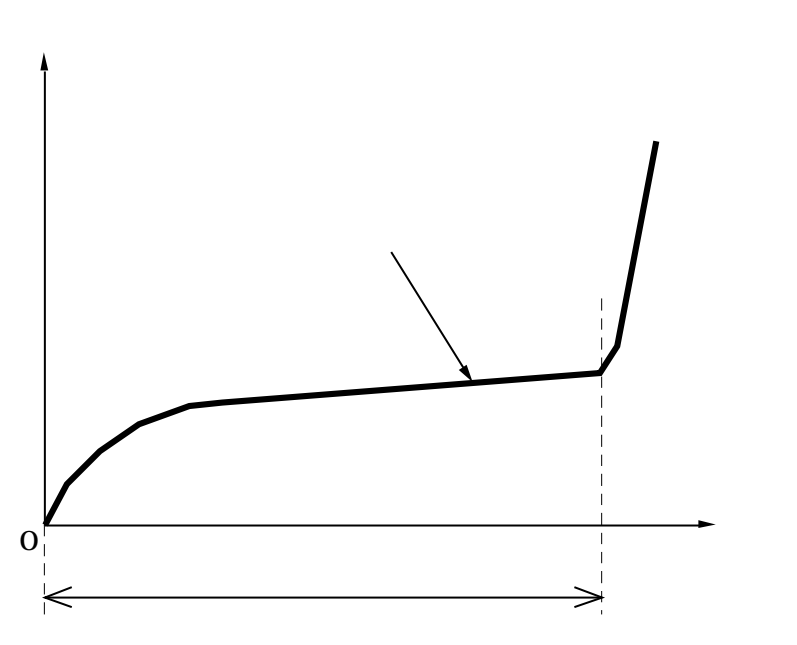

図- 2 沈下量 - 時間曲線

舗装試験法便覧に準ずる方法 ${ }^{5}$ )で行った．なお， 試験輪荷重を $686(\mathrm{~N})$ ，供試体厚さを $5 \mathrm{~cm}$ とした。

\section{（ 2）水浸ホイールトラッキング試験}

水浸ホイールトラッキング試験は, 図- 1 に示す とおり，上層に $300 \times 300 \times 40(\mathrm{~mm})$ の排水性等のアス ファルト混合物，下層にコンクリート版，境界層に ろ紙を敷いて設置した供試体上に車輪を走行させた． 水位は排水性混合物上面から $2 \mathrm{~cm}$ とした（下面から
$2 \mathrm{~cm})$

車輪の走行速度は骨材とアスファルトとのはく離 を促進するために，前報 ${ }^{6)}$ と同樣に 42 往復/分と した . トラバース速度は $100 \mathrm{~mm} /$ 分として, 走行試 験中の供試体上面の垂直変位量 (沈下量) の最大値 を自動記録した。

沈下量 - 時間曲線を描くと図- 2 に示すように急 激に沈下量が増加する現象が見られた ${ }^{3}$ ). この時間 を破壊時間とし，はく離による破壊に対する抵抗性 の指標とした .

\section{（3）耐油残留安定度試験}

車両から漏れる油分は排水性混合物内に浸透し， カットバックされたアスファルトが結合力を失い， ポットホールに進行していくと考えられている. 乥 こで本研究では東京都がおこなった実験 ${ }^{4)}$ を参考に して次のような手順で試験をした .

(1) マーシャル供試体を作製する .

(2) ガソリン内に供試体を上面まで浸す.浸漬時 間は $3,5,10$ 分とする.

(3) ガソリンから供試体を取り出して 1 日放置す る。

(4) マーシャル安定度を求めて, ガソリンに浸し てない供試体との安定度を比較して光の比率を 耐油性残留安定度とした。

\section{（4）透水試験および表面性状確認}

プラスチックが溶融した場合, 透水に必要な空隙 をつぶしてしまい，十分な透水機能を持たない可能 性がある，光こで，舗装試験便覧の現場透水試験に 準ずる方法 ${ }^{7}$ )で透水試験を行った．併せて耐油残留 安定度試験で作製したマーシャル供試体から連続空 隙率を調べ，さらに目視で表面性状を観察してプラ スチック混入による透水性, 表面性状の変化を考察 した。

\section{4.試験結果および考察}

\section{（1） ホイールトラッキング試験}

最大粒径 $13 \mathrm{~mm}$ 排水性混合物の結果を図- 3 , 最 大粒径 $5 \mathrm{~mm}$ 排水性混合物の結果を図-4 に示す. 図 - 3より最大粒径 $13 \mathrm{~mm}$ 排水性混合物に PE-3を $6 \%$ ， PE-2 を 8 \%混入することにより DS は 2 倍程度まで 上がった．他の条件では光れほど大きくならなかっ たが , プラスチックを混入しない混合物の DS より 小さくなることはなかった .

また，図一 4 で最大粒径 $5 \mathrm{~mm}$ 排水性混合物でも PP 


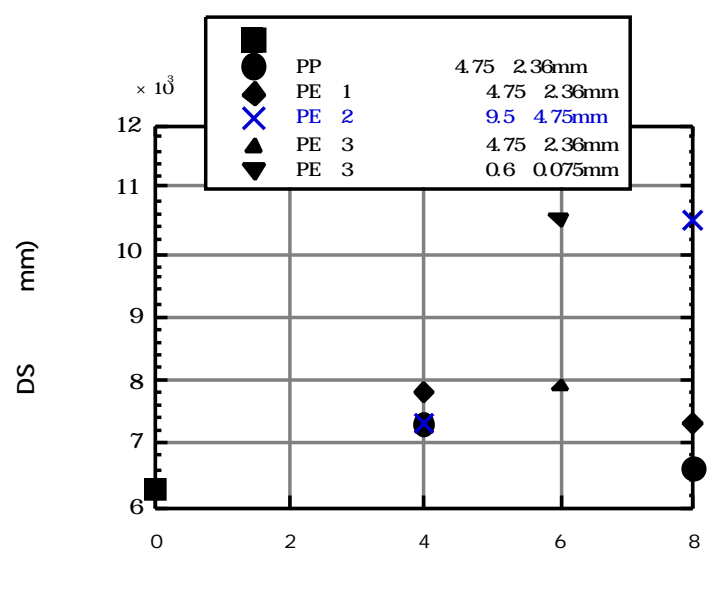

図- 3 DS-プラスチック混入量関係 (最大粒径 13mm排水性混合物)

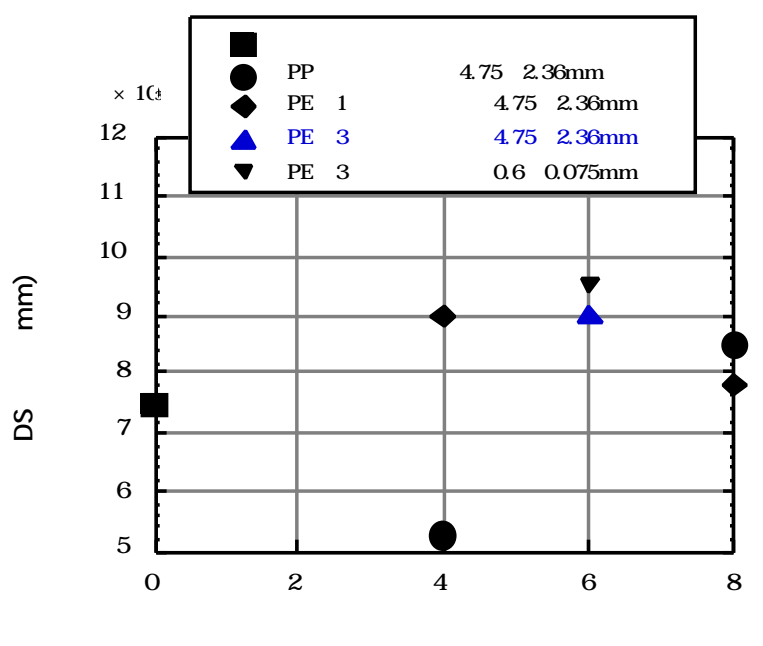

図-4 DS-プラスチック混入量関係 (最大粒径 $5 \mathrm{~mm}$ 排水性混合物)

を 4 \%混入した混合物では DS がプラスチックを混入 しなかった混合物に比べて小さくなっているが，光 の他の混合物ではDS は上がっている .

今回使用した排水性混合物は高粘度アスファルト を使用したために , プラスチックを混入しない状態 でも DS が大きくなった。したがって，弚の得られ た DS の数值の比較から単純に混合物の耐流動性の 比較をすることは，試験精度を考慮に入れると難し い．しかし，全体的に排水性混合物にプラスチック を混入すると DS は上がる傾向にある .

PE-3 を混入した場合では，今回実験したすべての 混合物の DS が上がった .これにより，PE-3 混入に より排水性混合物の耐流動性を損なうことはなく， 混入条件によっては高めることができる可能性があ ることが分かった .
表-4 置換骨材粒径の違いによる破壊時間への影 響 (PE-3 4\%混入)

\begin{tabular}{|c|c|c|c|}
\hline \multirow{2}{*}{$\begin{array}{c}\text { 混入量 } \\
(\%)\end{array}$} & \multirow{2}{*}{$\begin{array}{c}\text { 置換骨材 } \\
(\mathrm{mm})\end{array}$} & \multicolumn{2}{|c|}{ 破壊時間 (分) } \\
\hline & & $13 \mathrm{mmTOP}$ & $5 \mathrm{mmTOP}$ \\
\hline 0 & 混入なし & 530 & 500 \\
\hline \multirow{3}{*}{4} & $4.75 \sim 2.36$ & 620 & 680 \\
\hline & $2.36 \sim 0.6$ & 630 & 660 \\
\hline & $0.6 \sim 0.075$ & 1030 & 850 \\
\hline
\end{tabular}

表- 5 PE-3 混入量の違いによる破壊時間への影 響

\begin{tabular}{|c|c|c|c|}
\hline \multirow{2}{*}{$\begin{array}{c}\text { 混入量 } \\
(\%)\end{array}$} & \multirow{2}{*}{$\begin{array}{c}\text { 置換骨材 } \\
(\mathrm{mm})\end{array}$} & \multicolumn{2}{|c|}{$\begin{array}{l}\text { 破壊時間 (分) } \\
\end{array}$} \\
\hline & & $13 \mathrm{mmTOP}$ & $5 \mathrm{MmTOP}$ \\
\hline 0 & 混入なし & 530 & 500 \\
\hline 4 & $0.6 \sim 0.075$ & 1030 & 850 \\
\hline 6 & $0.6 \sim 0.075$ & 1600 & 1040 \\
\hline 10 & $2.36 \sim 0.075$ & 1620 & 1060 \\
\hline
\end{tabular}

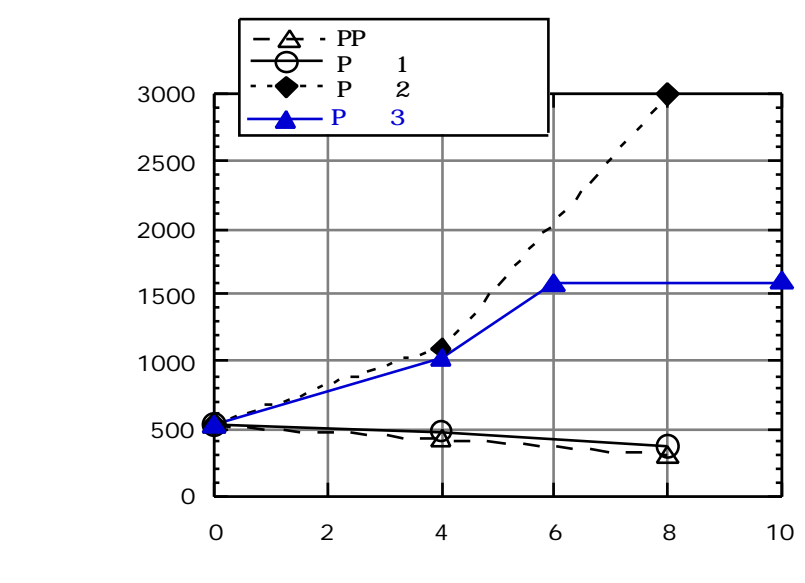

プラスチック混入量 $(\%)$

図- 5 破壊時間 - プラスチック混入量関係 (最大粒径 13mm 排水性混合物)

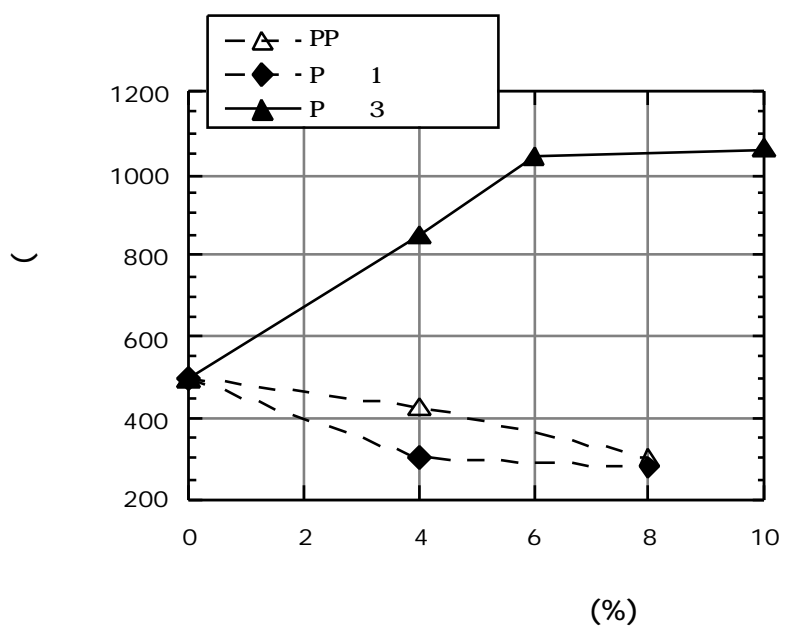

図- 6 破壊時間 - プラスチック混入量関係 


\section{（ 2）水浸ホイールトラッキング試験}

\section{a)PE-3 混入混合物の結果}

PE-3 は光の作製過程から粒径が広範囲に分布して いる. 兴のために，まず混入量を一定 $(4 \%)$ として 置換する骨材の粒径を変化させて試験を行った . 乥 の結果を表-4 に示す .これより置換する骨材の粒 径が小さいほど破壊時間が長くなった . 特に，0.6〜 0.075 $(\mathrm{mm})$ の骨材と置換した場合の変化が大きい .

表- 5 に PE-3 混入量の変化による破壊時間の変化 を示す.今回試験に使用した混合物の配合では $0.6 〜$ $0.075(\mathrm{~mm})$ の骨材は骨材体積の $6 \%$ 分であり，10\% 混入する場合は残りの $4 \%$ は $2.36 \sim 0.6(\mathrm{~mm})$ の骨材 から置換した .この結果から砕砂と置換する混入量 $6 \%$ までは破壊時間は長くなるが，残りの $4 \%$ を粒径 の大きい骨材と置換し，PE-3 の混入量を $10 \%$ に増や しても破壊時間は長くならなかった .

これらの結果には PE-3 の熱による可塑化が影響し ていると考えられる．PE-3 は熱により容易に溶融す る.しかし, ポリエチレンは溶融しても粘度が高く， 粘着性を持つ. PE-3 は粒径も小さいことから混合物 全体に広がり，粗骨材とアスファルトの付着に关の 粘着性が影響を与え, 骨材とアスファルトのみが接 着するよりも耐水性が向上するものと考えられる．

\section{b)PP, PE-1, PE-2 混入混合物の結果}

PP , PE-1 および PE-2 を混入した混合物と PE-3 混 入混合物の水浸ホイールトラッキング試験結果を図

表- 6 PE- 1, PE- 2 熱塑性性状比較

\begin{tabular}{|c|c|c|}
\hline 温度 & $P E-1$ & $P E-2$ \\
\hline 90 & 変化なし & \multirow{3}{*}{ 変化なし } \\
\hline 100 & 軟化し始める。 & \\
\hline 110 & \multirow{3}{*}{ 少し粒が崩れる。 } & \\
\hline 120 & & 若干柔らかくなる。 \\
\hline 130 & & 完全に溶融する。 \\
\hline 140 & $\begin{array}{l}\text { かなり粒が崩れる } \\
\text { が、完全に溶融し } \\
\text { ているとはいえな }\end{array}$ & \\
\hline
\end{tabular}

表- 7 マーシャル安定度比較

\begin{tabular}{|r|r|r|r|}
\hline \multirow{2}{*}{ 混合物 } & プラスチック & \multicolumn{2}{|c|}{ 混入プラスチック } \\
\cline { 3 - 4 } & の混入なし & $\mathrm{P} \mathrm{E}-1$ & $\mathrm{P} \mathrm{E}-2$ \\
\hline 密粒度 & 10.75 & 12.64 & 13.20 \\
\hline 排水性 & 4.90 & 4.97 & 6.99 \\
\hline
\end{tabular}

- 5, 図-6に示す.

図- 5 から PE-2 を混入した混合物は混入量が増加 すると破壞時間も長くなり，PE-2 混入により混合物 の耐はく離性能が向上していることが分かる．弚の 程度は PE-3 よりも大きい. しかし, PP と PE-1 は混 入することによって混合物の破壊時間が短くなる． この傾向は混入量を多くするほど著しい .

図- 6 からも混合物の最大粒径が変わっても PP と PE-1 は混入することによって混合物の破壊時間を短 くすることが分かる .

以上のように , 排水性混合物にプラスチックを混 入する際, 同種類のプラスチックでも混入による影 響が全く違う結果が生じた .これは同じ種類のプラ スチックであっても，熱による塑性性状が違うため

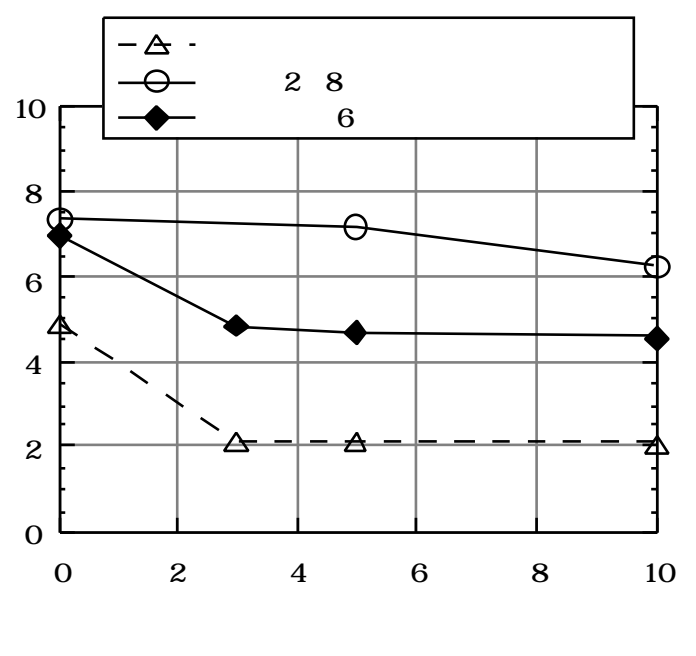

図- 7 安定度 - ガソリン浸漬関係

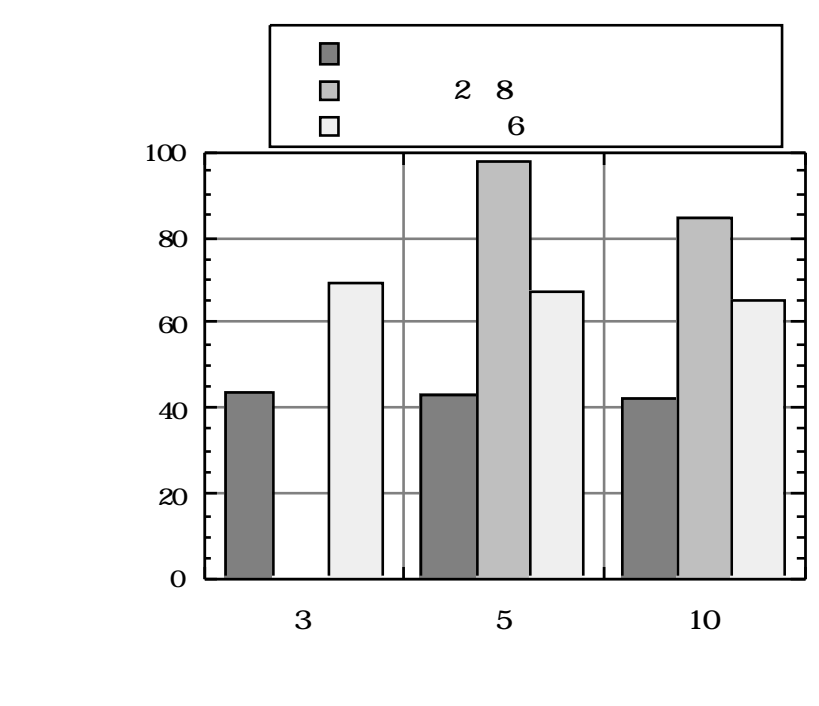

図- 8 残留安定度 - ガソリン浸漬関係 
に生じたと考えられる .

表一 6 に PE-1 と PE-2 の熱による塑性性状を観察 した結果を示す．PE-2 は軟化するとすぐに溶融し， 流れ出す．一方，PE-1 は軟化する温度は低いようで あるが，溶けて流れ出すことはほとんどない．

排水性混合物は密粒度混合物よりも空隙が大きく， また細骨材が少ないことで，流れ出していない PE-1 と粗骨材, アスファルトとをつなぎ止める要素が少 ないと考えられる．表- 7 のマーシャル安定度の結 果をみると，PE-2 混入混合物は密粒度混合物でも排 水性混合物でも安定度がプラスチックを混入しない 混合物よりも大きくなっているが, PE-1 混入混合物 の排水性混合物はプラスチックを混入しない混合物 と同程度となっている .

また，ポリエチレンの粘着力が十分に発揮できな いのであれば，PE-1 は球形をしており，表面の凸凹 も通常の骨材よりも少ないために，良質の骨材を使 用するよりも混合物の耐はく離性は悪くなる可能性 がある .

以上のことから同種類のプラスチックを混入して も，混入による破壊時間の変化の傾向が異なる．PE3 は熱によって PE-2 のように容易に溶融するために 破壞時間が長くなったものと考えられる .

\section{（3）耐油残留安定度試験}

耐油残留安定度試験では，水浸ホイールトラッ キング試験で破壊時間が長くなった PE-2，PE-3 混 入混合物とプラスチックを混入しない混合物を比 較した．混合物の種類は最大粒径 $13 \mathrm{~mm}$ 排水性混 合物で, 各試験值は 3 本の供試体の平均值とした .

図- 7 から安定度は初期の段階で PE-2，PE-3 を 混入した混合物のほうが大きくなっていることが 分かる . ガソリンに浸漬させるとプラスチックを 混入しない混合物は急激に安定度が下がる．PE-3 混入混合物の安定度も下がるが, 光の程度はプラ スチックを混入していない混合物よりも緩やかで， 10 分浸漬後の安定度は混入しない混合物の初期の 安定度と同程度であった . PE-2 混入混合物は安定 度の低下がほとんどみられなかった 。

図-8に残留安定度とガソリン浸漬時間関係を 示すが，これより明らかに PE-2，PE-3 を混入した 混合物のガソリンによる安定度の低下が減少して いることが分かる .これは, ポリエチレンは耐油 性のある物質であり，これが溶融して，光の粘着 性からアスファルトと骨材の接着に関係すること により，混合物の耐油性が向上するものと考えら れる。

\section{（4）現場透水試験および表面性状確認}

混合物内でプラスチックが溶融することで，排水 性混合物に要求される空隙率が確保できなかったり， 転圧の際に溶融したプラスチックが表面の空隙を埋 めたり，粘着性を増すために転圧機に混合物が付着 して表面の仕上がりが悪くなる懸念がある .

乥こで, 各混合物の透水量, 空隙率, 有効空隙率 を測定し，表面性状の観察をおこなった．乥の結果 を表- 8, 表- 9 に示す.これらの結果からプラスチ ックを混入しても透水量, 空隙率に大きな変化はな く，特に透水量は十分に確保されている.しかし， 特に PE-2 を混入した混合物は表面にプラスチックが 溶融して空隙を潰し, 転圧ローラーに付着して表面 に凸凹が多くなった．写真- 1 と写真- 2 をみると， PE-2 混入混合物の空隙が不均一になっていることが 分かる. 透水量としては数值として満足できている が，目視により確認できる表面性状には問題がある．

写真- 3 には PE-3 混入混合物の表面の状態を示す . ポリエチレンが溶融してアスファルトと混ざるため にプラスチックを混入しない混合物と比較して光沢 を持った色となった．しかし，表面の空隙はほぼ均 一に分布しており，表面の凸凹もほとんどみられな かった .

表- 8 混合物の透水量・空隙率・表面性状 (最大粒径 $13 \mathrm{~mm}$ 排水性混合物)

\begin{tabular}{|l|r|r|r|c|c|}
\hline 混入プラ & $\begin{array}{c}\text { プラ混入量 } \\
\text { (\%) }\end{array}$ & $\begin{array}{c}\text { 透水量 } \\
(\mathrm{ml} / 15 \mathrm{~s})\end{array}$ & $\begin{array}{c}\text { 空隙率 } \\
(\%)\end{array}$ & $\begin{array}{c}\text { 効空隙率 } \\
(\%)\end{array}$ & $\begin{array}{c}\text { 表面性状 } \\
\text { (目視) }\end{array}$ \\
\hline 混入なし & 0 & 1181.9 & 21.4 & 17.2 & 良 \\
\hline $\mathrm{PE-1}$ & 4 & 1263.2 & 19.9 & - & 良 \\
\cline { 2 - 7 } & 8 & 1224.5 & 20.2 & - & や荒 \\
\hline $\mathrm{PE}-2$ & 4 & 1263.2 & 20.4 & - & 荒 \\
\hline & 8 & 1224.5 & 20.9 & 18.6 & 荒 \\
\hline $\mathrm{PE}-3$ & 4 & 1196.2 & 19.8 & - & 良 \\
\cline { 2 - 7 } & 6 & 1202.4 & 20.2 & 17.3 & 良 \\
\hline
\end{tabular}

表- 9 混合物の透水量・空隙率・表面性状 (最大粒径 $5 \mathrm{~mm}$ 排水性混合物)

\begin{tabular}{|l|r|r|r|c|}
\hline 混入プラ & $\begin{array}{c}\text { プラ混入量 } \\
(\%)\end{array}$ & $\begin{array}{c}\text { 透水量 } \\
(\mathrm{ml} / 15 \mathrm{~s})\end{array}$ & $\begin{array}{c}\text { 空隙率 } \\
(\%)\end{array}$ & $\begin{array}{c}\text { 表面性状 } \\
(\text { 目視 })\end{array}$ \\
\hline 混入なし & 0 & 1164.5 & 21.4 & 良 \\
\hline PE-1 & 4 & 1234.6 & 20.6 & やや荒 \\
\cline { 2 - 6 } & 8 & 1237.1 & 21.8 & やや荒 \\
\hline PE-3 & 4 & 1134.6 & 21.2 & 良 \\
\cline { 2 - 6 } & 6 & 1184.2 & 21.6 & やや荒 \\
\hline
\end{tabular}




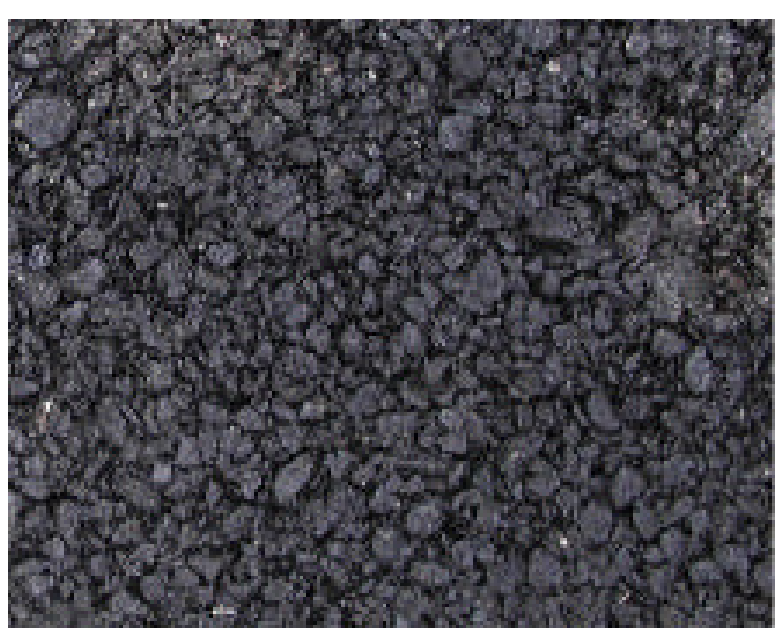

写真- 1 プラスチック混入なし混合物表面性状

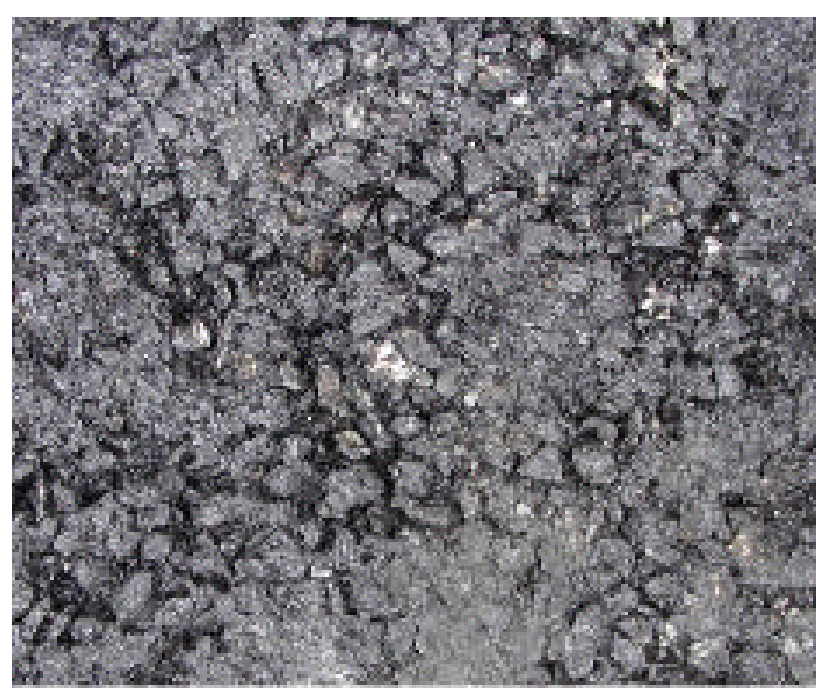

写真- 2 PE- 2 8\%混入混合物表面性状

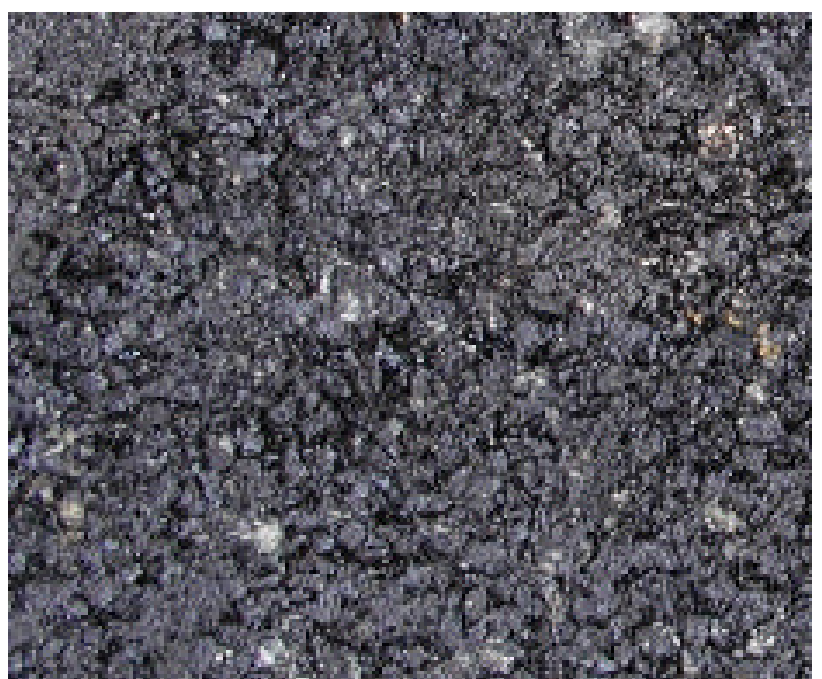

写真- 3 PE-3 6\%混入混合物表面性状（砕砂と 置換
このような P E - 2 と P E - 3の表面形状の違いは， $P E-2$ は 6 号砕石と同等の粒径であり, 熱によっ て溶融すると粗骨材ほどの大きさの粘着力をもった 大きな塊となり，転圧の際に空隙を埋め，周辺骨材 とともにローラーに付着するものと考えられる .方, PE-3 は砕砂と置換しており，溶融して粗骨材と ほぼ均等に付着する．弚のために表面の空隙を不均 一に埋めることはなく，またローラーと付着しても アスファルトと均等に混ざっているために粗骨材が ローラーに付着しない .

\section{5.結論}

1) ペットボトルラベル再生ペレットを排水性混合 物に混入することにより DS が上がり，光の混入 条件によっては, 混合物の耐流動性を高めること ができる可能性がある .

2) ペットボトルラベル再生ペレットを 4.75 2.36 $(\mathrm{mm})$, あるいは 2.36〜0.6 $(\mathrm{mm})$ の骨材部分と 置換した場合は水浸ホイールトラッキング試験の 破壊時間は混入しない場合と比べて長くなったが， 増加量はわずかであった . 弚れよりも細かい $0.6 〜$ $0.075(\mathrm{~mm})$ と置換した場合に破壞時間が大きく 増加した。

3) 耐油性のあるポリエチレンが溶融し , アスファ ルトと混ざることにより，排水性混合物の耐油性 能が向上する .

4) ペットボトルラベル再生ペレットを排水性混合 物に混入した場合, 透水量, 空隙率, 表面の性状 にも目立った影響はなかった 。

以上より，今後さらに試験施工を含め，詳細な検 討が必要だが, ペットボトルの再生ペレットを排水 性アスファルト混合物に混入して利用できる可能性 があることが分かった .

\section{参考文献}

1) 山田優，稲葉慶成：廃プラスチックのアスファルト混 合物用材料としての利用,舗装，Vol.29，No.7，pp.17-22， 1994.

2）鎌田修, 山田優 : プラスチック粒入りアスファルト 混合物の動的安定度と疲労破壊特性, 第 21 回日本道路 会議論文集 (B )，pp.616-617，1995.

3) 山端一浩, 山田優, 袴田文雄, 前川順道: 水浸ホイ 一ルトラッキング試験による橋梁床版上排水性舗装の 耐久性の検討,土木学会論文集, No.606/V - 41,pp.21-29， 1998.

4) 峰岸順一, 田中輝栄：低騷音舗装のポットホールの 
破損の実態と原因，舗装，Vol.37，No.3，pp.3-9，2002.

5) 日本道路協会 : 舗装試験法便覧，pp.539-555，1988.

6) 鎌田修, 山田優：水浸ホイールトラッキング実験に よる橋面舗装でのポットホールの発生と光の要因, 舗装 工学論文集,pp.196-201，2001.

7）日本道路協会：舗装試験法便覧，pp.926-929，1988.

\section{THE EFFECT OF MIXING THE PELLET RECLAIMED FROM PET BOTTLE LABEL IN POROUS ASPHALT MIXTURE}

\section{Osamu KAMADA and Masaru YAMADA}

The recycle of PET bottle is advanced in recent years. But the utilization of reclaimed productions of PET bottle label is limited, because of these color. And dense graded asphalt mixture mixed with polyethylene is exceeded in anti-fluidity and anti-cracking of bended. So in this study, the effect of mixing the pellet reclaimed from PET bottle label in porous asphalt mixture was examined. For the results, the time of failure examined by immersion wheel tracking test was longer and the retained stability examined by anti-oil stability test was improved. For these, the resistance of stripping caused by standing water and of destruction caused by the leak of oil by car is improved by using this pellet in porous asphalt mixture. 